CZASOPISMO INŻYNIERII LĄDOWEJ, ŚRODOWISKA I ARCHITEKTURY JOURNAL OF CIVIL ENGINEERING, ENVIRONMENT AND ARCHITECTURE

JCEEA, t. XXXIV, z. 64 (1/17), styczeń-marzec 2017, s. 105-112, DOI:10.7862/rb.2017.10

Adam SZELĄGOWSKI ${ }^{1}$

\title{
KLIMATYZACJA Z WYKORZYSTANIEM SORPCYJNO-WYPARNYCH SYSTEMÓW CHLODZENIA
}

\begin{abstract}
Sorpcyjno-wyparne systemy chłodzenia DEC (ang. desiccant evaporation cooling) stanowią alternatywę dla klasycznych systemów klimatyzacji wykorzystujących sprężarkowe urządzenia chłodnicze. Stosowanie systemów DEC pozwala na obniżenie zużycia energii elektrycznej przez systemy klimatyzacyjne nie pogorszając przy tym jakości powietrza dostarczanego do pomieszczeń. Nie wykorzystują przy tym „freonowych” czynników chłodniczych, dzięki czemu nie mają negatywnego wpływu na środowisko. W technologii DEC powietrze chłodzone jest poprzez odparowanie wody, aby zwiększyć efekt chłodzenia powietrze wstępnie jest osuszone przy zastosowaniu stałych, bądź ciekłych sorbentów. Do regeneracji sorbentów, wymagają dostarczenia ciepła o temperaturze w zakresie $50-100^{\circ} \mathrm{C}$. Ze względu na możliwość wykorzystania odpadowych i odnawialnych źródeł ciepła technologia DEC stanowi interesujące rozwiązanie. W artykule opisano zasadę działania systemu DEC, oraz przedstawiono wyniki obliczeń dla systemu pracującego w warunkach letnich w klimacie umiarkowanym. Obliczenia wykonane zostały przy założeniu temperatury powietrza zewnętrznego równej $27^{\circ} \mathrm{C}$, wilgotność względną przyjmowano z przedziału $45-80 \%$ zmieniając tę wartość co $5 \%$. Do analizy przyjęto stałe zyski ciepła jawnego i utajonego wewnątrz przestrzeni klimatyzowanej, które wynoszą odpowiednio $15 \mathrm{~kW}$ i $3 \mathrm{~kW}$. Strumień powietrza wentylacyjnego przyjęto na poziomie $1000 \mathrm{~m}^{3} / \mathrm{h}$. Wyniki obliczeń pokazują, że w zakresie wilgotności względnej powietrza zewnętrznego poniżej $60 \%$ systemy DEC są w stanie zapewnić odpowiednią jakość powietrza wentylacyjnego, oraz odebrać zyski ciepła i wilgoci z pomieszczeń klimatyzowanych. Wybrany sorbent, do regeneracji wymaga dostarczenia strumienia ciepła o temperaturze około $70^{\circ} \mathrm{C}$, w ilości trzykrotnie większej w stosunku do strumienia ciepła jaki jest do odebrania z pomieszczeń.
\end{abstract}

Słowa kluczowe: komfort cieplny, chłodzenie wyparne, wentylacja, klimatyzacja, sorpcyjne osuszanie powietrza

${ }^{1}$ Adam Szelągowski, Politechnika Warszawska, Instytut Techniki Cieplnej, ul. Nowowiejska 21/25, 00-665 Warszawa; adam.szelagowski@itc.pw.edu.pl 


\section{Wprowadzenie}

Stosowanie systemów klimatyzacji ma zapewnić uczucie satysfakcji z warunków cieplnych środowiska, w którym aktualnie przebywa człowiek. Wtedy mówimy o komforcie termicznym. W przeciwieństwie do prostych systemów ochładzania powietrza, które jedynie utrzymują zadaną temperaturę powietrza wewnątrz pomieszczeń, pełna klimatyzacja komfortu ma za zadanie utrzymać nastawioną temperaturę jak i wilgotność powietrza wewnątrz pomieszczeń, oraz zapewnić odpowiednią jego jakość. Klasyczne urządzenia klimatyzacyjne pobierają duże ilości energii elektrycznej, co wiąże się z dość wysokimi kosztami eksploatacyjnymi. Chęć obniżenia kosztów, oraz racjonalnego wykorzystywania energii, sprawia, że warto zastanowić się nad rozwiązaniami konstrukcyjnymi urządzeń wentylacyjnych i klimatyzacyjnych, które mają zmniejszony pobór energii, lub wykorzystują energię odpadową bądź odnawialną. Jednym z takich rozwiązań w technice obróbki powietrza jest system klimatyzacyjny DEC (Desiccant and Evaporative Cooling). W systemach tych, do schładzania powietrza wykorzystuje się efekt obniżania temperatury powietrza przy jego adiabatycznym nawilżaniu [2]. Aby zwiększyć efektywność tego procesu powietrze jest wstępnie osuszane, przy wykorzystaniu stałych bądź ciekłych sorbentów. Odpowiednie sterowanie całym procesem pozwala utrzymać wartość temperatury i wilgotności powietrza na poziomie zapewniającym komfort cieplny. Aby system mógł pracować w sposób ciągły niezbędna staje się regeneracja sorbentów. $\mathrm{W}$ zależności od użytego sorbentu wymagane jest ciepło o temperaturze w zakresie $50-100^{\circ} \mathrm{C}$ [3]. Ze względu na możliwość użycia ciepła odpadowego lub ze źródeł odnawialnych np. energii słonecznej, technologia stanowi interesującą alternatywę w stosunku do klasycznych systemów klimatyzacji [1].

\section{Komfort cieplny i klimat wewnętrzny}

Zagadnienie komfortu cieplnego stanowi bardzo ważny aspekt życia. Organizm człowieka posiada pewne zdolności dostosowania się do warunków otoczenia. Zdolności te są jednak ograniczone, natomiast człowiek czuje się najlepiej w pewnych określonych warunkach klimatycznych. Za najwłaściwszą temperaturę powietrza w strefie przebywania ludzi można uznać tę, która zapewnia ciału ludzkiemu równowagę cieplną z otaczającym środowiskiem. Dla większości ludzi normalnie ubranych, wykonujących pracę lekką, lub pozostających $\mathrm{w}$ stanie spoczynku, temperatura powietrza $\mathrm{w}$ strefie przebywania ludzi, zapewniająca dobre samopoczucie wynosi $20-24^{\circ} \mathrm{C}$ [6]. Drugim ważnym parametrem powietrza, mającym duży wpływ na odczucia cieplne jest wilgotność powietrza. Przy temperaturze powietrza na poziomie $16-24{ }^{\circ} \mathrm{C}$ wilgotność względna powietrza w granicach $40-60 \%$ ma neutralny wpływ na odczucia cieplne człowieka. Wilgotność względna powietrza poniżej $35 \%$, może powodować wysuszenie śluzówki nosa i skóry. Gdy temperatura i wilgotność wzrastają jednocze- 
śnie, organizm ludzki zaczyna odczuwać nadmiar pary wodnej w powietrzu, zmniejsza się odparowanie z powierzchni skóry, co utrudnia odprowadzenie ciepła z ciała. W przypadku określania granic warunków komfortu powinno się przyjmować względną wilgotność tym niższą im wyższa jest temperatura powietrza. Utrzymanie latem temperatury i wilgotności, wewnątrz pomieszczeń, na odpowiednim poziomie (temperatury $-20 \div 26^{\circ} \mathrm{C}$ i wilgotności względnej $40 \div 60 \%$ ) wymaga stosowania urządzeń klimatyzacyjnych.

\section{Zasada działania systemu DEC}

Powietrze zewnętrze zasysane jest do układu przez wentylator nawiewny. Strumień powietrza przepływa przez rotor sorpcyjny, gdzie wilgoć z powietrza jest adsorbowana (rysunek 1). Rotor sorpcyjny ma wysoką temperaturę, przez co temperatura powietrza nawiewanego za rotorem rośnie. Przemianę powietrza nawiewanego w rotorze sorpcyjnym na wykresie Molliera (rysunek 2) przedstawia linia 1-2. Ogrzane i osuszone powietrze następnie przepływa przez rekuperator, w którym się ochładza nie zmieniając przy tym zawartości wilgoci. Przemianę obrazuje linia 2-3.

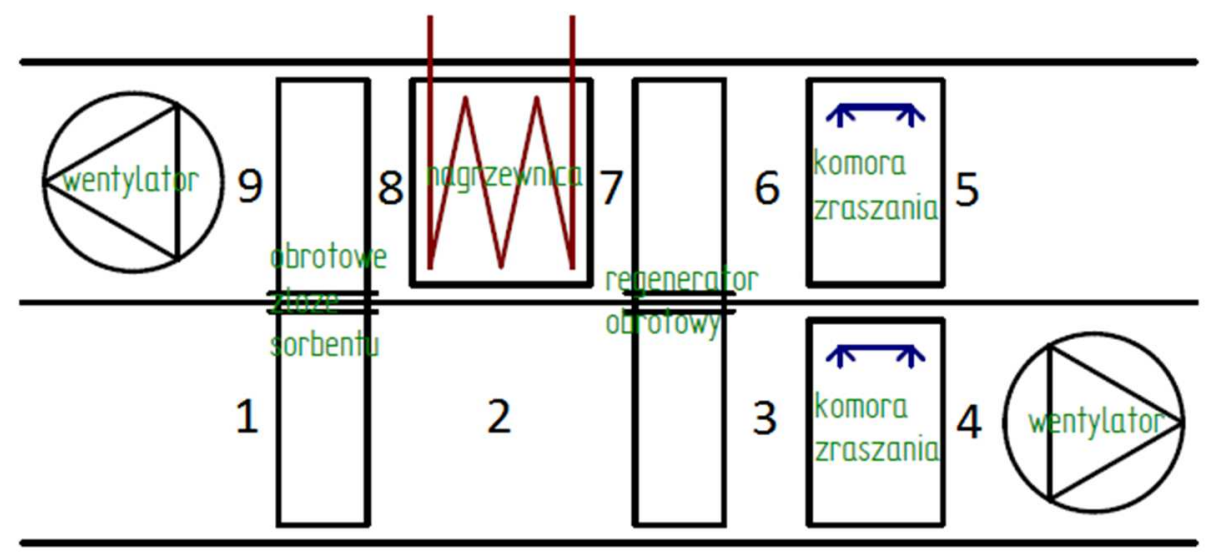

Rys. 1. Schemat centrali klimatyzacyjnej w systemie DEC

Fig. 1. Concept of the desiccant cooling system

Powietrze nawiewane przepływa następnie przez nawilżacz adiabatyczny. W wyniku rozpylania wody nad strumieniem powietrza część rozpylanej wody odparowuje, odbierając od powietrza ciepło. W wyniku przepływu strumienia powietrza przez nawilżacz adiabatyczny jego temperatura spada, natomiast zawartości wilgoci rośnie. Aby proces nawilżania był adiabatyczny, temperatura rozpylanej wody musi mieć wartość równą temperaturze nasycenia dla powietrza przepływającego przez nawilżacz (temperatura termometru mokrego) [8]. Teoretycznie możliwą do osiągnięcia temperaturą powietrza $\mathrm{w}$ nawilżaczu adiabatycznym 
jest temperatura nasycenia dla tego powietrza. W praktyce jednak powietrze nie jest schładzane tak bardzo, a temperaturę do jakiej powietrze jest schładzane w nawilżaczu można określić znając efektywność procesu nawilżania [3].

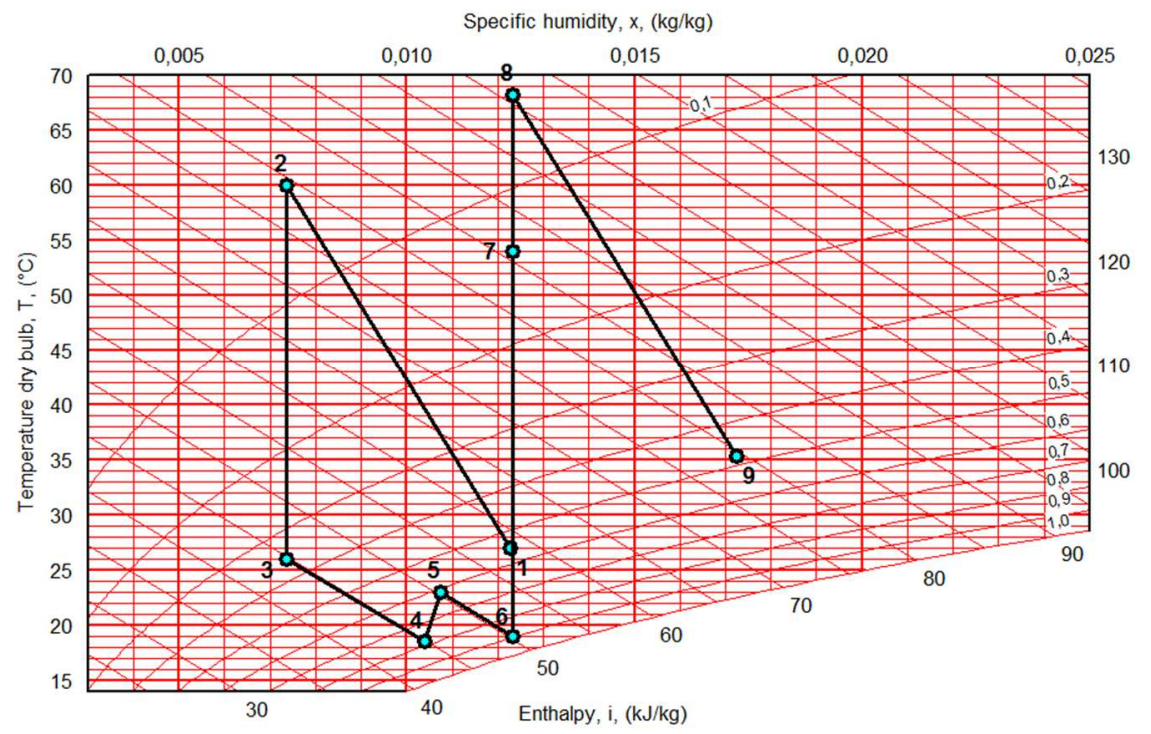

Rys. 2. Przemiany powietrza zachodzące w systemie DEC przedstawione na wykresie psychometrycznym [7]

Fig. 3. Psychometric chart showing a typical desiccant cooling process [7]

Schłodzony i nawilżony strumień powietrza doprowadzany jest do klimatyzowanych pomieszczeń, gdzie miesza się z powietrzem wewnętrznym. W wyniku niwelowania zysków ciepła jawnego i utajonego nawiewany strumień powietrza ogrzewa się i zwiększa zawartość wilgoci [4]. Przemianę na rysunku 2 przedstawia linia 4-5.

W celu utrzymania poprawnej pracy centrali klimatyzacyjnej DEC konieczna jest regeneracja jej wymienników. Regeneracji dokonuje się wykorzystując strumień powietrza wywiewanego z pomieszczenia. Strumień powietrza wywiewanego z pomieszczenia przepływa najpierw przez nawilżacz adiabatyczny, w którym się ochładza i nawilża - proces 5-6. Następnie przepływa przez wymiennik regeneracyjny, w którym zostaje ogrzany - przemiana 6-7. Wartość temperatury strumienia powietrza w punkcie 7 , nie pozwala jeszcze na efektywną regenerację rotora sorpcyjnego. Najpierw temperaturę strumienia powietrza należy jeszcze dodatkowo podnieś. Dokonuje się tego w nagrzewnicy. Strumień powietrza wywiewanego przepływając przez nagrzewnicę zwiększa swoją temperaturę - przemiana 7-8. Następnie powietrze wywiewane przepływa przez rotor sorpcyjny. Gorące powietrze działa regenerująco na rotor odbierając wilgoć zaadsorbowaną z powietrza nawiewanego, przemiana - 8-9. 


\section{Analiza pracy systemu DEC}

Analizę pracy układu DEC przeprowadzono przy założeniu temperatury powietrza zewnętrznego równej $27^{\circ} \mathrm{C}$, oraz przy różnej wilgotności względnej tego powietrza. W obliczeniach wilgotność względną przyjmowano z przedziału $45-80 \%$ zmieniając tę wartość co $5 \%$. Do analizy przyjęto stałe zyski ciepła jawnego i utajonego wewnątrz przestrzeni klimatyzowanej, które wynoszą odpowiednio $15 \mathrm{~kW}$ i $3 \mathrm{~kW}$. Strumień powietrza wentylacyjnego dobrano tak, aby dla przyjętej temperatury powietrza zewnętrznego i przy jego wilgotności względnej równej 55\% był $\mathrm{w}$ stanie odebrać zyski ciepła $\mathrm{z}$ pomieszczenia i utrzymać $\mathrm{w}$ nim wartość temperatury na poziomie $23^{\circ} \mathrm{C}$. Wyznaczony strumień powietrza wentylacyjnego wynosi $1000 \mathrm{~m}^{3} / \mathrm{h}$. W analizie przyjęto pewne uproszczenia zakładając stałe efektywności: procesu sorpcji wilgoci z powietrza nawiewanego równej $0,4[5,8]$, procesów nawilżania równej 0,75 , oraz odzysku ciepła w regeneratorze równej $0,8[6]$.

W systemach DEC powietrze usuwane z układu powinno regenerować złoże $\mathrm{w}$ rotorze sorpcyjnym. W przypadku obliczeniowym powietrze regeneracyjne powinno zostać ogrzane do temperatury $68,25^{\circ} \mathrm{C}$. Wymaga to zastosowania nagrzewnicy o mocy równej około $50 \mathrm{~kW}$. Oprócz tego uwzględniono moc wentylatorów potrzebnych do przetłoczenia wymaganego strumienia powietrza wentylacyjnego, która wynosi $5 \mathrm{~kW}$.

Na rysunku 3 przedstawiony jest wpływ wartości wilgotności względnej powietrza zewnętrznego na możliwą do osiągnięcia temperaturę powietrza nawiewanego do pomieszczeń klimatyzowanych, oraz wilgotność względną utrzymywaną w tych pomieszczeniach, dla analizowanego systemu.

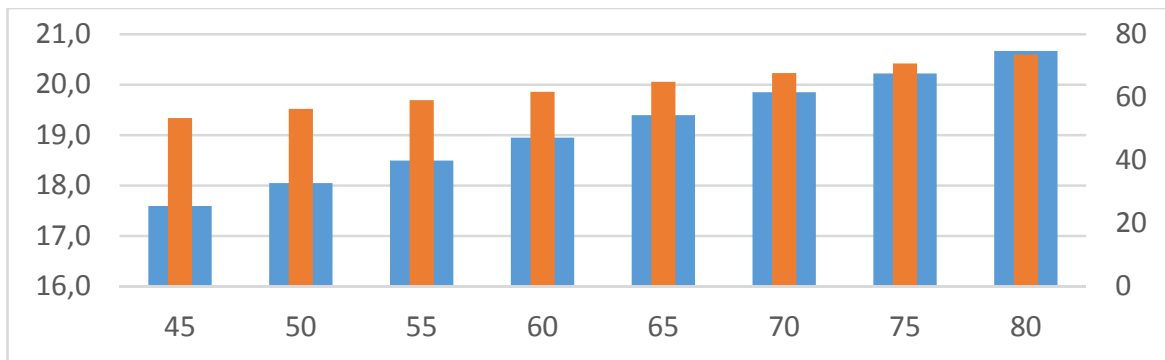

- temp. powietrza nawiewanego [st.C] — wilgotność względna w pomieszczeniu [\%]

Rys. 3. Wpływ wilgotności powietrza zewnętrznego na temperaturę powietrza nawiewanego do pomieszczenia i wilgotność w pomieszczeniu, przy chłodzeniu systemami DEC

Fig. 3. Effect of outdoor air humidity on the temperature of the supply air and the indoor humidity in the DEC system 
Na rysunku 4 przedstawiony jest wpływ wartości wilgotności względnej powietrza zewnętrznego na wydajność chłodniczą systemu, wymagany strumień ciepła do regeneracji sorbentu, oraz wartość współczynnika efektywności chłodniczej analizowanego systemu.

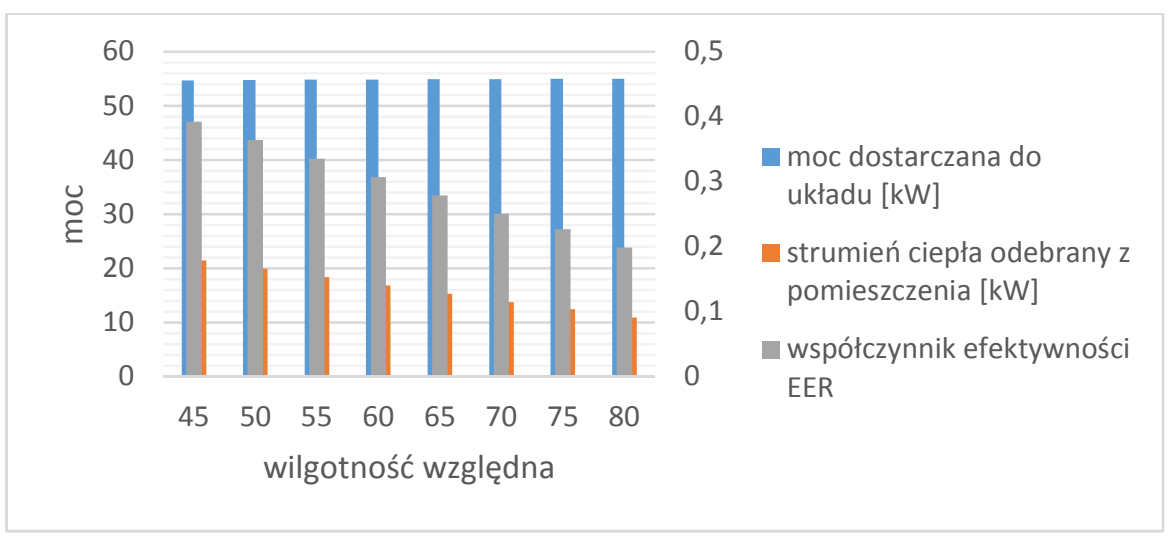

Rys. 4. Wpływ wilgotności powietrza zewnętrznego na wydajność i efektywność chłodzenia, oraz moc potrzebną do regeneracji w systemach DEC

Fig. 4. Effect of outdoor air humidity on the performance, cooling efficiency, and the power required for the regeneration in the DEC system

W przypadku wyższych wartości wilgotności powietrza zewnętrznego system nie jest $\mathrm{w}$ stanie odebrać założonego strumienia ciepła $\mathrm{z}$ pomieszczenia. Zapotrzebowanie na moc grzewczą głównie zależy od strumienia powietrza wentylacyjnego, natomiast mniejsze znaczenie mają parametry powietrza zewnętrznego. Wzrost wilgotności względnej powietrza zewnętrznego powyżej $65 \%$ uniemożliwia utrzymania wilgotności względnej w pomieszczeniu na poziomie zapewniającym komfort. Aby system był w stanie zapewnić odpowiednie warunki w pomieszczeniu niezbędne jest zapewnienie dużego strumienia powietrza wentylacyjnego. Wybrany sorbent, do regeneracji wymaga dostarczenia strumienia ciepła o temperaturze $68,25^{\circ} \mathrm{C}$. W przypadku, gdy układ odbiera z pomieszczenia zyski ciepła równe $18 \mathrm{~kW}$ wymaga dostarczenia strumienia ciepła równego 49,8 kW a do przetłoczenia powietrza pracy wentylatorów o mocy $5 \mathrm{~kW}$. Uwzględniając powyższe, system osiąga współczynnik efektywności energetycznej równy 0,34. Analizowane rozwiązanie wydaje się dobre w przypadku niskiej wilgotności powietrza zewnętrznego i kiedy dysponujemy tanim ciepłem w dużej ilości. 


\section{Wnioski}

Systemy DEC są interesującym rozwiązaniem i mają duży potencjał w dziedzinie klimatyzacji. Układy charakteryzują się prostą budową. Aby systemy były opłacalne do regeneracji sorbentów powinno być wykorzystane źródło ciepła odpadowego lub odnawialnego np. energia gromadzona w kolektorach słonecznych.

Efektywność systemu jest zależna od parametrów powietrza zewnętrznego. W zakresie wilgotności względnej powietrza zewnętrznego poniżej $60 \%$ systemy DEC są w stanie zapewnić odpowiednią jakość powietrza wentylacyjnego, oraz odebrać zyski ciepła i wilgoci z pomieszczeń klimatyzowanych. Współczynnik efektywności energetycznej analizowanego systemu wynosi 0,34.

\section{Literatura}

[1] Badyda K.: Współczesne technologie chłodnicze a wykorzystanie energii słonecznej, Polska energetyka słoneczna, nr 2, 2005, s. 21-26.

[2] Daou K., Wang R.Z., Xia Z.Z.: Desiccant cooling air conditioning: a review, Renewable and Sustainable Energy Reviews, no.10, 2004, pp. 55-77.

[3] Jarocki P., Rusowicz A.: System DEC w klimacie umiarkowanym, Chłodnictwo, nr 4, 2009, s. 32-36.

[4] Khoukhi M.: A Study of Desiccant-Based Cooling and Dehumidyfying System in Hot-Humid Climate, International Journal of Materials, Mechanics and Manufacturing, vol.1, no.3, 2013, pp.191-194.

[5] NovelAire Technologies: Desiccant Dehumidification Wheel Technical Brochure, http://www.novelaire.com/images/pdfs/dw-brochure.pdf \{dostęp 9.05.2016 r.\}.

[6] Pełech A.: Wentylacja i klimatyzacja: podstawy, wydanie trzecie, Oficyna Wydawnicza Politechniki Wrocławskiej. Wrocław 2011.

[7] Program Mollier Sketcher.

[8] Yadav A., Yadav L.: Comparative performance of desiccant wheel with effective and ordinary regeneration sector using mathematical model, Heat and Mass Transfer, vol.50, no.10, 2014, pp. 1465-1478.

\section{AIR CONDITIONING USING DESICCANT EVAPORATION COOLING SYSTEM}

\section{S u m m a r y}

Desiccant evaporation cooling systems (DEC) are an alternative to conventional vaporcompression cooling units. The use of DEC systems reduces the electricity consumption of air conditioning systems and do not deteriorating the quality of supplied air at the same time. They do not use refrigerants, so do not have a negative impact on the environment. In DEC technology cooling effect is achived by evaporation of water. To increase the cooling effect first the air is dehumidified by a solid or liquid sorbent. Regeneration of sorbents requires the input of heat at a temperature in the range of $50-100^{\circ} \mathrm{C}$. Due to the possibility of using waste, or renewable heat 
the DEC technology is an interesting solution. This paper describes the principle of operation of the DEC, and showing the influence of some operating parameters for a system efficiency. Calculations were made with the assumption of an outdoor air temperature at the $27^{\circ} \mathrm{C}$, relative humidity was taken between $45-80 \%$ by changing the value by $5 \%$. For the analysis a sensible and latent heat gains inside the conditioned space were assumed, respectively $15 \mathrm{~kW}$ and $3 \mathrm{~kW}$. Ventilation air flow is assumed to be $1000 \mathrm{~m}^{3} / \mathrm{h}$. The calculation results show that for the relative humidity of the outside air below $60 \%$ DEC systems are able to ensure the required quality of ventilation air, and take of the heat and moisture gains from the air-conditioned space. The selected sorbent regeneration requires the heat flux at a temperature of about $70^{\circ} \mathrm{C}$, in an amount three times as compared to the heat flow taken from the air conditioned space.

Keywords: thermal comfort, evaporative cooling, ventilation, air-conditioning, sorption air dehumidification

Przestano do redakcji: 11.01.2017 r.

Przyjęto do druku: 31.03.2017 r. 